\title{
Genetic variation among South Brazilian accessions of Lippia alba Mill. (Verbenaceae) detected by ISSR and RAPD markers
}

\author{
Manica-Cattani, MF., Zacaria, J., Pauletti, G., Atti-Serafini, L. and Echeverrigaray, S.* \\ Instituto de Biotecnologia, Universidade de Caxias do Sul - UCS, \\ Rua Francisco Getúlio Vargas, 1130, CEP 95001-970, Caxias do Sul, RS, Brazil \\ *e-mail selaguna@yahoo.com \\ Received July 10, 2007 - Accepted September 9, 2007 - Distributed May 31, 2009
}

(With 3 figures)

\begin{abstract}
Twenty-seven accessions of Lippia alba Mill. collected in Rio Grande do Sul state, Brazil, were analysed by ISSR and RAPD markers to evaluate their genetic variability and relationships. Six ISSR primers and four RAPD primers generated 120 amplified fragments, most of which were polymorphics. The overall genetic variability among accessions was very high when compared with other plant species. The hierarchical analysis of molecular data (UPGMA) showed low relationship between accessions, and no grouping between accessions of the same chemotype. Canonical functions allowed identifying some variables related with the chemical characteristics of the essential oils. Both ISSR and RAPD markers were efficient to address the genetic diversity of $L$. alba, and may contribute to the conservation and breeding of this increasingly important aromatic and medicinal species.
\end{abstract}

Keywords: molecular relationship, ISSR, RAPD, Lippia alba, Verbenaceae.

\section{Variabilidade genética entre acessos sul-brasileiros de Lippia alba Mill. (Verbenaceae) detectada por ISSR e RAPD}

\begin{abstract}
Resumo
Vinte e sete acessos de Lippia alba Mill. coletados no Rio Grande do Sul, Brasil, foram analisados por marcadores ISSR e RAPD visando avaliar a variabilidade genética e as relações entre acessos. Seis sequencias iniciadoras de ISSR e quatro de RAPD geraram 120 fragmentos amplificados, a maior parte dos quais apresentaram algum grau de polimorfismo. A variabilidade genética geral entre acessos foi muito elevada quando comparada com outras espécies vegetais. A análise hierárquica dos dados moleculares (UPGMA) mostrou baixa relação entre acessos, e não houve formação de agrupamentos entre acessos pertencentes ao mesmo quimiotipo. Análise de funções canônicas permitiu identificar algumas variáveis relacionadas com as características químicas dos óleos essenciais. Tanto os marcadores ISSR como RAPD foram eficientes para avaliar a diversidade genética em $L$. alba e devem contribuir para a conservação e melhoramento desta importante espécie aromática e medicinal.
\end{abstract}

Palavras-chave: associações moleculares, ISSR, RAPD, Lippia alba, Verbenaceae.

\section{Introduction}

The genus Lippia (Verbenaceae) is formed by approximately 200 species of scrubs or herbaceous plants widely distributed throughout the tropical, subtropical and temperate regions of America, Africa and Asia (Terblanché and Kornelius, 1996). Lippia alba Mill. is one of the American species of the genus, popularly known as "cidreira brava", "cidreira da arbusto", "falsa Melissa", "salvia morada", among others (Martins and Santos, 1995). Originating from the Andes (Chile, Peru), it is actually found in all the subtropical and tropical regions of South America, Central America and the Caribbean islands.

Extracts and infusions of leaves and flowers of L. alba are used in the popular medicine of several coun- tries for the treatment of colds, flu, bronchitis, coughs, asthma, fever, diarrhea and other disorders (Alea et al., 1996; Vale et al., 1999). Spasmolytic, analgesic, cytostatic, anticonvulsivant and antiulcerogenic activities have been proved and attributed to the essential oils of $L$. alba (Alea et al., 1996; Matos, 1998; Viana et al., 1998).

Evaluation of the essential oil composition of L. alba accessions showed high qualitative and quantitative variations. For example, Zoghbi et al. (1998) reported the presence of three chemotypes (citral, limonene/carvone, and 1.8-cineole) among samples from Para state, Brazil, while limonene and piperitone were the main components of the essential oils of L. alba collected in Guatemala 
(Senatore and Rigano, 2001). In similar works, Lorenzo et al. (2001) reported a linalool chemotype in Uruguay, and Stashenko et al. (2003) showed the presence of carvona and limone chemotypes in Colombia. Inter and intra population variability in essential oil composition represents a serious problem for the commercialisation of L. alba for medicinal purposes.

To minimize the problem of chemical variability, efficient processes of stem cutting (Biasi and Costa, 2003) and micropropagation (Gupta et al., 2001) have been developed to obtain genetic and chemical uniform clones form selected accesses of L. alba. Moreover, methods for the fast and accurate identification of genotypes, cultivars uniformity determination, and the evaluation of the genetic variability would be of substantial benefit for the certification of cultivars with specific medicinal properties, and the management of germplasm banks and breeding programs.

Random amplified polymorphic DNA (RAPD) markers (Williams et al., 1990) and Inter simple sequence repeat (ISSR) markers (Zietkiewicz et al., 1994) have been used with success to identify and determine relationships at the species, population and cultivar levels in many plant species, including several aromatic and medicinal plants (e.g. Sangwan et al., 1999; Nan et al., 2003; Torres et al., 2003; Fracaro et al., 2005; Mattioni et al., 2002). These methods are widely applicable because there are rapid, inexpensive, require small amounts of template DNA and, unlike SSR markers, do not require prior knowledge of DNA sequences (Godwin et al., 1997).

Considering the increasing importance of L. alba as a medicinal plant, and the limited knowledge regarding the genetic diversity of this species, the present work aimed to determine the efficiency of ISSR and RAPD markers for the identification of $L$. alba genotypes, and the evaluation of the genetic variability among accesses with different chemotypes collected in Rio Grande do Sul state, Brazil.

\section{Material and Methods}

\subsection{Plant materials}

In this work we analyzed 27 accessions of Lippia alba collected in different localities of Rio Grande do Sul state, Brazil, and on the Uruguayan frontier. Each accession represents an individual plant propagated by stem cutting. These accessions make part of the germplasm collection of the Institute of Biotechnology of the University of Caxias do Sul. The list of accessions with the corresponding chemotypes is present in Table 1.

\subsection{Amplification and evaluation of ISSR and RAPD markers}

Total DNA was extracted from $200 \mathrm{mg}$ of fresh leaf tissue of each plant by the CTAB method described by Doyle and Doyle (1990). DNA concentration and quality was evaluated at 260 and $280 \mathrm{~nm}$. The $\mathrm{A}_{260 / 280}$ ration ranged between 1.8 and 1.9. DNA integrity was confirmed by gel electrophoresis on $0.8 \%$ agarose on TBE buffer $(50 \mathrm{mM}$ Tris, $50 \mathrm{mM}$ boric acid, $2.5 \mathrm{mM}$ EDTA, $\mathrm{pH}$ 8.3).
The RAPD amplification reactions (final volume of $25 \mu \mathrm{L}$ ) contained: $10 \mathrm{mM}$ Tris- $\mathrm{HCl}(\mathrm{pH} 8.4), 50 \mathrm{mM} \mathrm{KCl}$,

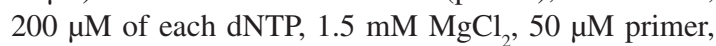
$1 \mathrm{U}$ Taq-polymerase, and $25 \mathrm{ng}$ of plant DNA. ISSR reactions were similar except for primer concentration $(30 \mu \mathrm{M})$ and $0.8 \mathrm{U}$ Taq-polymerase.

The amplification conditions for ISSR and RAPD were an initial step of 5 minutes at $94{ }^{\circ} \mathrm{C}$ followed by 40 cycles of 1 minute at $94{ }^{\circ} \mathrm{C}$ for denaturing, $45 \mathrm{~s}$ at $40{ }^{\circ} \mathrm{C}$ (RAPD) or 48 to $50{ }^{\circ} \mathrm{C}$ ISSR (Table 2) for annealing, and 2 minutes at $72{ }^{\circ} \mathrm{C}$ for extension, and a final extension of 5 minutes at $72{ }^{\circ} \mathrm{C}$.

Amplification products were resolved by electrophoresis in $1.5 \%\left(\mathrm{w}_{\mathrm{v}} \mathrm{v}^{-1}\right)$ agarose gels in TBE buffer under a constant voltage of $90 \mathrm{~V}$. DNA fragments were stained with $1 \mu \mathrm{g} . \mathrm{mL}^{-1}$ ethidium bromide and digitalized under UV light for further analysis. Bacteriophage Lambda cut with EcoRI and HindIII was included as size standard on each gel.

\subsection{Data analysis}

The bands were assigned molecular weights based upon their positions relative to a Lambda molecular weight stand-

Table 1. L. alba accessions and corresponding chemotypes.

\begin{tabular}{rll}
\hline & \multicolumn{1}{c}{ Origin } & \multicolumn{1}{c}{ Chemotype } \\
\hline 1 & Erechim - Campo & caryophyllene \\
2 & Uruguaiana & n.d. \\
3 & Pelotas & cineole/camphor \\
4 & Santana do Livramento I & linalool \\
5 & Teutônia & citral \\
6 & Arroio do Sal II & linalool \\
7 & Ijuí II & citral \\
8 & Guarda do Embaú & citral \\
9 & Ijuí III & caryophyllene \\
10 & Caxias do Sul I & linalool \\
11 & Chui (Uruguay) & linalool \\
12 & Santa Vitória do Palmar & camphor \\
13 & São Miguel & cineol/camphor \\
14 & Erechim - Estufa & caryophyllene \\
15 & Porto Alegre & citral \\
16 & Santana do Livramento II & n.d. \\
17 & Chuí (Brazil) & linalool \\
18 & Giruá & linalool \\
19 & Ijuí IV & camphor \\
20 & Ijuí I & citral \\
21 & Pinheira & Carvone \\
22 & Caçapava do Sul & cineol/camphor \\
23 & Barra do Quarai & limonene \\
24 & São Borja & n.d. \\
25 & Arroio do Sal I & linalool \\
26 & Harmonia & caryophyllene \\
27 & Caxias do Sul II & linalool \\
\hline & & \\
\hline & &
\end{tabular}


Table 2. ISSR and RAPD primers used, number of polymorphic bands and Simpson Index for 27 L. alba accessions.

\begin{tabular}{llccccc}
\hline \multicolumn{1}{c}{ Primer } & Sequence* & $\begin{array}{c}\text { Anneling } \\
\text { Temp. }\left({ }^{\circ} \mathbf{C}\right)\end{array}$ & $\begin{array}{c}\mathbf{N}^{\mathbf{0}} \text { of } \\
\text { bands }\end{array}$ & $\begin{array}{c}\mathbf{N}^{\mathbf{0}} \text { polymorphic } \\
\text { bands }\end{array}$ & $\begin{array}{c}\mathbf{N}^{\mathbf{0}} \text { monomorphic } \\
\text { bands }\end{array}$ & $\begin{array}{c}\text { Simpson } \\
\text { Index }\end{array}$ \\
\hline ISSR 1 & $(\mathrm{AC})_{8}{ }_{\mathrm{T}}$ & 50 & 20 & 19 & 1 & 0.721 \\
ISSR 2 & $(\mathrm{GA}){ }_{8} \mathrm{Y}$ & 50 & 13 & 11 & 2 & 0.577 \\
ISSR 3 & $(\mathrm{CTC})_{4} \mathrm{RC}$ & 48 & 9 & 6 & 3 & 0.352 \\
ISSR 4 & $(\mathrm{AG})_{8} \mathrm{YC}$ & 50 & 9 & 8 & 1 & 0.668 \\
ISSR 5 & $(\mathrm{GACA}){ }_{4}$ & 48 & 7 & 6 & 1 & 0.542 \\
ISSR 6 & $(\mathrm{CA})_{8} \mathrm{G}$ & 50 & 9 & 5 & 4 & 0.529 \\
& & & $\mathbf{6 7}$ & $\mathbf{5 5}$ & $\mathbf{1 2}$ & $\mathbf{0 . 5 6 5}$ \\
RAPD - OPZ-12 & TCAACGGGAC & 40 & 17 & 17 & 0 & 0.706 \\
RAPD - OPZ-08 & GGGTGGGTAA & 40 & 17 & 15 & 2 & 0.696 \\
RAPD - OPA-11 & CAATCGCCGT & 40 & 11 & 8 & 3 & 0.559 \\
RAPD - OPZ-01 & TCTGTGCCAG & 40 & 8 & 6 & 2 & 0.541 \\
& & & $\mathbf{5 3}$ & $\mathbf{4 6}$ & $\mathbf{7}$ & $\mathbf{0 . 6 2 5}$ \\
& & & $\mathbf{1 2 0}$ & $\mathbf{1 0 1}$ & $\mathbf{1 9}$ & $\mathbf{0 . 5 8 9}$ \\
\hline
\end{tabular}

$* \mathrm{Y}=\mathrm{C}$ or $\mathrm{T} ;$ and $\mathrm{R}=\mathrm{A}$ or $\mathrm{G}$.

ard. ISSR and RAPD amplicons were scored for presence or absence in each accession, and the data were entered into a binary matrix as discrete variables (' 1 ' presence and ' 0 ' absence). The discrimination potential of each primer was expressed by the Simpson's coefficient $\left(\mathrm{h}_{\mathrm{j}}=\Sigma\left(1-\Sigma \mathrm{p}_{\mathrm{i}}^{2}\right) / \mathrm{n}\right)$, where $\mathrm{p}_{\mathrm{i}}$ is the frequency of the $\mathrm{i}^{\text {th }}$ allele, and $n$ corresponds to the number of loci detected by each primer (Tian et al., 2005). For all pairs of genotypes, genetic similarity values were calculated using the Jaccard coefficient (Sneath and Sokal, 1973), which does not include 0-0 matches as an indicator of similarity. Using genetic similarity matrices, a dendrogram was constructed according to the unweighted pair-group method with arithmetic average (UPGMA). The relation between genetic and chemical data was determined by AMOVA and canonical function analysis. Data were analyzed using the SPSS 10.0 (SPSS Inc., Chicago, Illinois) and GenAlEx (Peakall and Smouse, 2001) programs.

\section{Results}

\subsection{Selection of primers}

Initially 17 primers of ISSR and 15 decameric primers of RAPD were screened against total DNA from three accessions of L. alba (Erechim, Pelotas and Teutônia) to select a set of primers that allowed the amplification of several polymorphic segments of medium to hard intensity, between 200 and 2,000 bp, and with high reproducibility $(>95 \%)$ in three independent amplification experiments. Of the 17 ISSR primers, five produced no distinct bands, four resulted in very faint bands on a smeary background, and two produced just monomorphic bands. The remaining six primers (Table 2) produced robust and reproducible patterns. Of the 15 RAPD decameric primers, four were selected based on the amplification pattern and reproducibility (Table 2). An example of the patterns obtained with $(\mathrm{GACA})_{8}$ and OPZ-08 are shown in Figure 1.
The selected ISSR and RAPD primers used to amplify all the accessions yielded 65 and 55 fragments, respectively, resulting in a total of 120 bands most of which were polymorphics $(84.1 \%)$. Primer $(\mathrm{GACA})_{8}$ resulted in the smallest number of bands (7) and primer $(\mathrm{AC})_{8} \mathrm{~T}$ generated the largest number of bands (20). The average number of bands per primer was 12 . The size of amplification product varied between 250 and 2,500 bp with an average size of $~ 890 \mathrm{bp}$.

\subsection{Genetic variability}

The percentage of polymorphic bands obtained with RAPD and ISSR methods was similar, $86.8 \%$ and $82.1 \%$, respectively. However, the discrimination ability of the primers (Simpson Index) varied between 0.352 and 0.721 . However, similar average Simpson indexes were obtained with both methods (Table 2). The high average Simpson coefficient (0.589) indicates high genetic variability among the accessions of Lippia alba collected in south Brazil. The distribution of the allelic frequencies showed that most alleles are present in high $(>0.90)$ or low $(>0.10)$ frequency, an expected fact, considering the dominant nature of both RAPD and ISSR markers.

Identical RAPD and ISSR profiles were obtained for the two plants of the Erechim accession evaluated confirming the clonal origin of the accessions, and just two primers were enough to discriminate all the other possible pair-wise comparisons between accessions.

Mantel analysis between the Jaccard similarity coefficients calculated based on the presence or absence of RAPD and ISSR markers showed that they were highly correlated (0.778), and could therefore be processed jointly. Jaccard similarity coefficients estimated using the overall (ISSR and RAPD) data ranged from 0.384 (Chuí Brasil versus Chuí Uruguay) to 0.803 (São Miguel versus Santa Vitória do Palmar), with an average of $0.570 \pm 0.079$.

A dendrogram resulting from cluster analysis (UPGMA) did not differentiate groups among the accessions of L. alba 

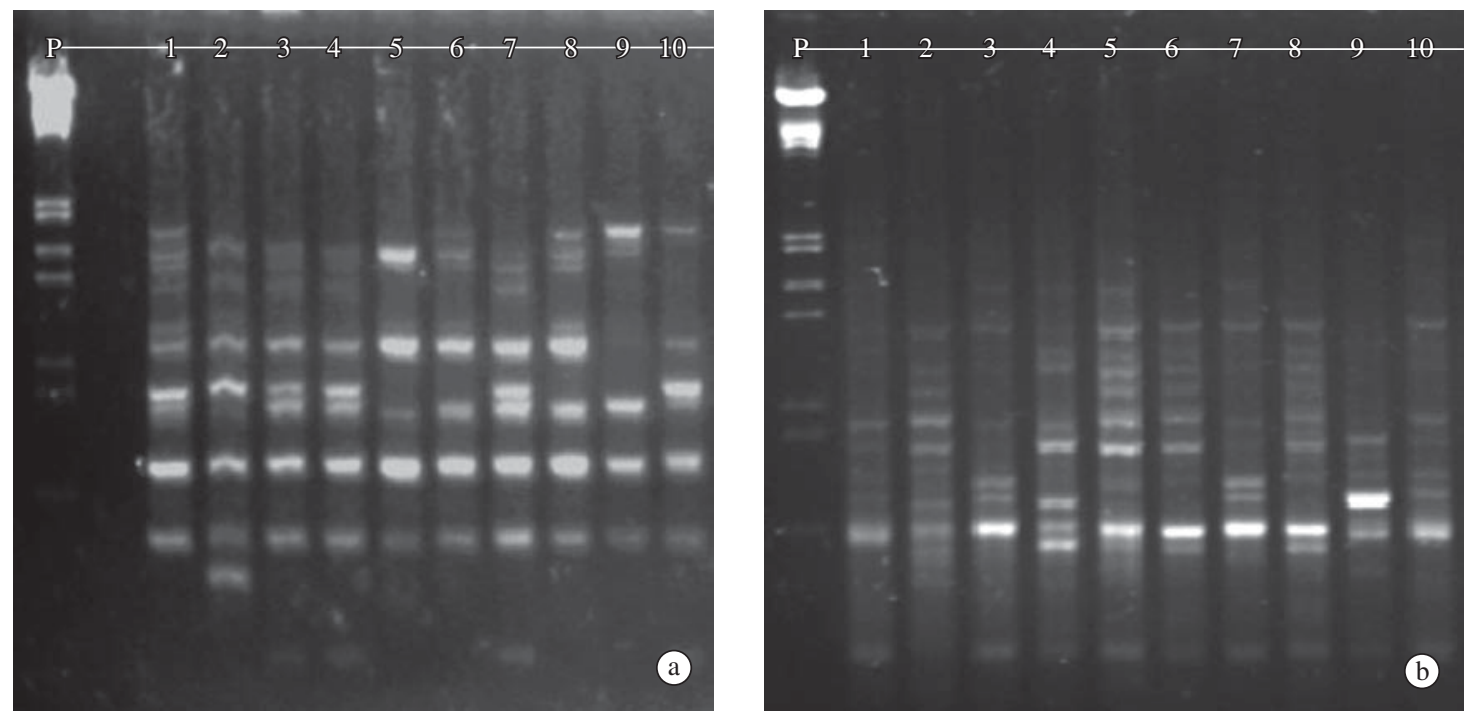

Figure 1. RAPD OPA-11 a) and ISSR (GACA) ${ }_{8}$ and b) profiles of Brazilian accessions of Lippia alba. P- Lambda EcoRI/ HindIII. Accessions: 1) Erechim; 2) Uruguaiana; 3) Pelotas; 4) Santana do Livramento I; 5) Teutonia; 6) Arroio do Sal II; 7) Ijuí II; 8) Guarda do Embaú; 9) Ijuí III; and 10) Caxias do Sul I.

(Figure 2). However, a weak tendency, not confirmed by AMOVA analysis of variance, was observed in the distribution of the different chemotypes on the dendrogram.

Canonical discriminant analysis (Figure 3) of molecular data and chemotypes showed that several molecular markers are associated with the main components of the essential oils of the accessions. Amplicons $\mathrm{CTC}_{431}, \mathrm{CTC}_{564}$, $\mathrm{AG}_{1475}, \mathrm{AC}_{1161}, \mathrm{OPZ12}{ }_{459}, \mathrm{OPZ8}_{1714}$, and $\mathrm{OPZ1} 1_{1737}$ separate the accessions of the caryophyllene chemotype (Erechim campo, Erechim estufa, Ijuí III, and Harmonia) from the others, and amplicons $\mathrm{AG}_{1072}, \mathrm{GA}_{635}, \mathrm{GA}_{1285}, \mathrm{OPZ1}_{820}$, $\mathrm{OPZ8}_{800}$, and $\mathrm{OPZ8}_{454}$ grouped the accessions of the linalool (Santana do Livramento I, Arroio do Sal II, Caxias do Sul I and II, Chui - Uruguay and Brazil, and Giruá) and cineole/camphor (Pelotas, São Miguel, and Caçapava do Sul) chemotypes separating them from those of the citral chemotype (Teutônia, Ijuí I and II, Porto Alegre).

\section{Discussion}

Until now, the identification of $L$. alba accessions, one of the most important aromatic and medicinal plants of South America, has relied on morphological and chemical characters (Zoghbi et al., 1998, Senatore and Rigano, 2001, Lorenzo et al., 2001 Stashenko et al., 2003). However, the low number of descriptors and the quantitative nature of most of these characters limit the efficiency of genotypes characterization. The present results show that molecular markers, ISSR and RAPD, efficiently identify L. alba genotypes allowing the characterization of all the different accessions under study. In fact, using only two primers it was possible to identify all the accessions. Moreover, both ISSR and RAPD markers exhibited high reproducibility. In only one case (RAPD primer OPZ-08) did a selected band $\left(\mathrm{OPZ}_{620}\right)$ fail to be reproduced in a subsequent amplification. The efficiency of these molecular markers for genotype identification in other aromatic and medicinal plants (Sangwan et al., 1999; Nan et al., 2003; Torres et al., 2003; Fracaro et al., 2005; Mattioni et al., 2002), and the characterisation of Lippia species (Viccini et al., 2004) have been reported.

The genetic variability among Brazilian accessions of $L$. alba as evidenced by the average Simpson index (0.589) is very high when compared with other cultivated and wild plant species (Sangwan et al., 1999; Gobert et al., 2002; Lee et al., 2002; Mattioni et al., 2002; Fracaro et al., 2005). Although evaluating a low number of accessions per species, Viccini et al. (2004) evidenced high genetic variation (RAPD markers) among natural populations of Lippia sidoides and L. hermanoides from southeast Brazil. Moreover, the U-shape distribution of the allelic frequencies, observed with both RAPD and ISSR markers, is common in natural populations of outcrossing plant species with a large genetic background (Chakraborty et al., 1980).

As reported in other plant species (Archak et al., 2003; Awasthi et al., 2004; Bhattacharya et al., 2005) high correlation was observed between the distances obtained with RAPD and ISSR allowing the joint analysis of all the amplification products.

No groups were formed by the cluster analysis of the molecular data confirming that each accession represents a unique genetic entity, and that genetic variation was not associated with the geographical origin. In fact that is expected, as the accessions are cultivated plants propagated by stem cutting and not local populations.

Although no relation was observed between the overall genetic variability and the essential oil composition, several markers were able to separate accessions of some chemotypes, as indicated by canonical analysis. This relation did not implicate in linkage between the markers and genes that 


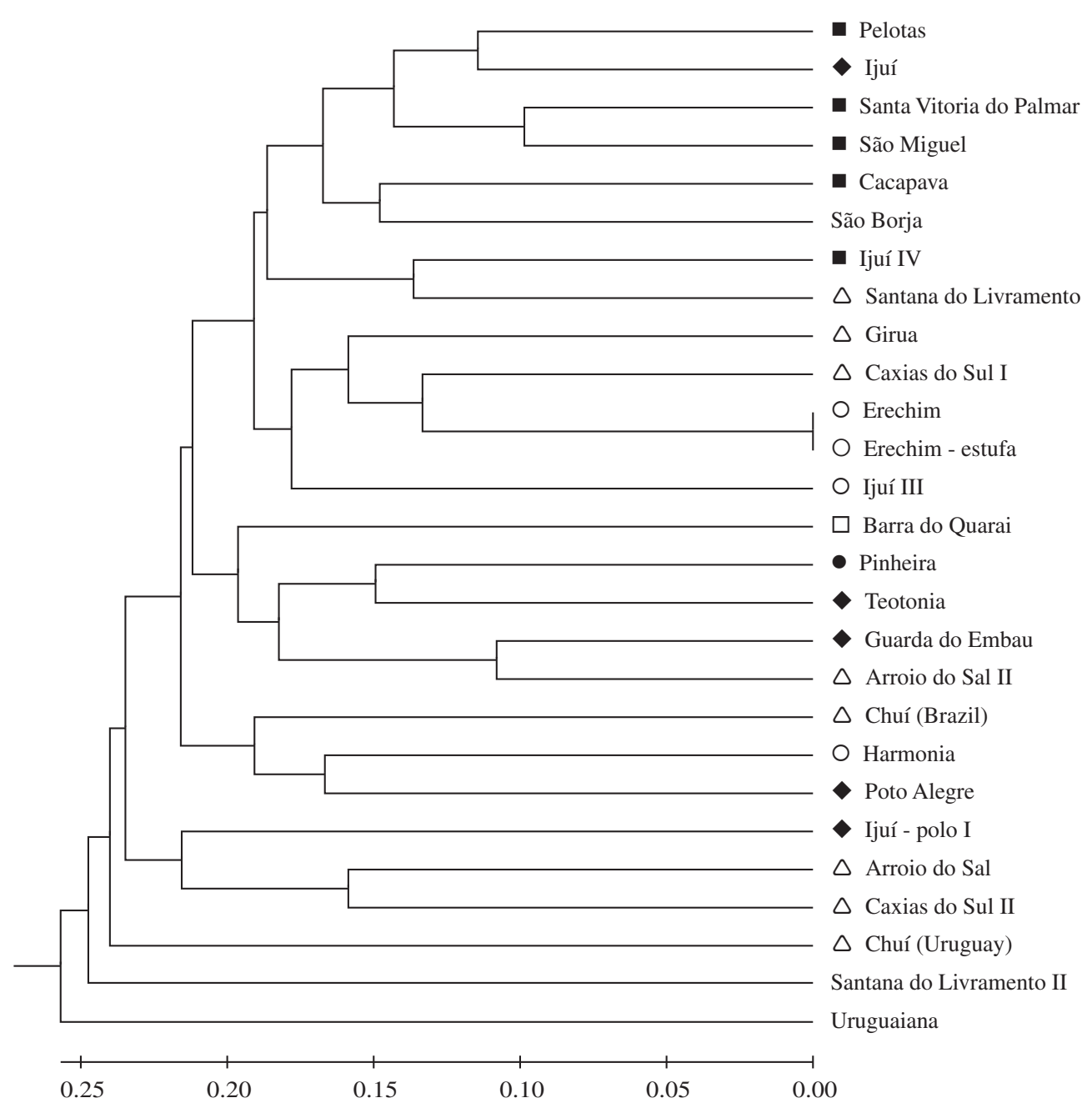

Figure 2. A hierarchical cluster analysis dendrogram of 27 accessions of $L$. alba based on the variation of ISSR and RAPD patterns. Chemotypes:

cineole/camphor; $\square$ limonene; $\bullet$ carvone; $\bigcirc$ caryophyllene;

citral; and $\triangle$ linalool.

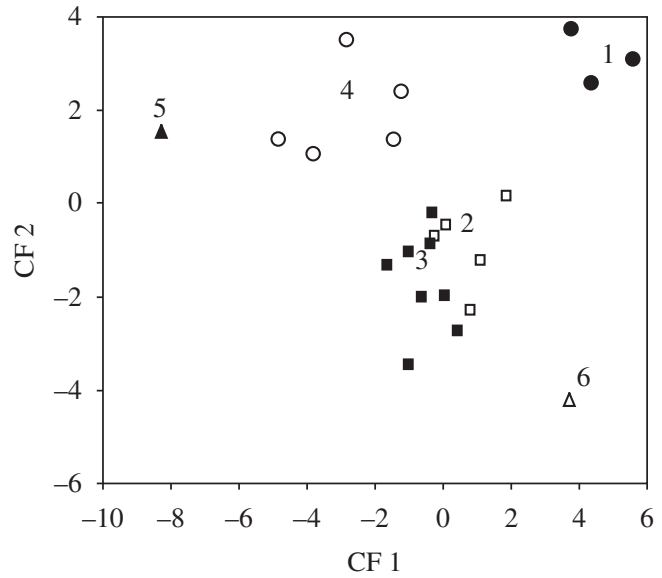

Figure 3. Stepwise canonical discriminant analysis of the 27 accessions of $L$. alba chemotypes 1) caryohyllene; 2) cineole/camphor; 3) linalool, 4) citral; 5) carvone; and 6) limoneno, based on ISSR and RAPD data. participate in terpenes biosynthesis, but a possible common origin of accessions of a given chemotype. In this sense, the relation between genetic and chemical variability reported in population studies of several aromatic and medicinal species (e.g. Keskitalo et al., 2001; Fracaro et al., 2005) was associated with the genetic origin of the populations.

The analysis of genetic variability, population analysis, evaluation of gene flow, among other parameters, integrating information obtained by molecular analyses and ecological studies allow the development of conservation strategies (Heywood and Iriondo, 2003; Escudero et al., 2003). In this sense, the high genetic and chemical variability, and the presence of rare alleles, indicate that large germplasm collections are necessary to represent the overall genetic variability of $L$. alba. Moreover, genetic information may represent a useful tool for the selection of representative genotypes, the production of new populations, and the management of breeding programs of this species. 


\section{References}

ALEA, JAP., LUIS, AGO., PÉREZ, AR, JORGE MR. and BALUJA R., 1996. Composición y propiedades antibacterianas del aceite esencial de Lippia alba (Mill.) N.E. Brown. Revista Cubana de Farmacia, vol. 30, no. 1. Available from: <http:// scielo.sld.cu/scielo.php?script=sci_arttextandpid=S003475151 996000100007 andlng=esandnrm=iso $>$.

ARCHAK, S., GAIKWAD, AB., GAUTAN, D., RAO, EV., SWAMY, KR. and KARIHALOO, JL., 2003. Comparative assessment of DNA fingerprinting techniques (RAPD, ISSR and AFLP) for genetic analysis of cashew (Anacardium occidentale L.) accessions of India. Genome, vol. 46, no. 3, p. 362-369.

AWASTHI, AK., NAGARAJA, GM., NAIK, GV., KANGINAKUDRU, S., THANGAVELU, K. and NAGARAJU, J., 2004. Genetic diversity and relationships in mulberry (genus Morus) as revealed by RAPD and ISSR markers. BMC Genetics, vol. 5 , p. 1.

BHATTACHARYA, E., DANDIN, SB. and RANADE, SA., 2005. Single primer amplification reaction methods reveal exotic and indigenous mulberry varieties are similarly diverse. Journal of Biosciences, vol. 30, no. 5, p. 669-677.

BIASI, LA. and COSTA, G., 2003. Propagação vegetativa de Lippia alba. Ciência Rural, vol. 33, no. 3, p. 455-459.

CHAKRABORTY, R., FUERST, PA. and NEI, M., 1980. Statistical studies on protein polymorphism in natural populations. III. Distribution of allele frequencies and the number of alleles per locus. Genetics, vol. 94, no. 4, p. 1039-1063.

DOYLE, J. and DOYLE, JL., 1990. Isolation of plant DNA from fresh tissue. Focus, vol. 75, no. 1, p. 13-15.

ESCUDERO, A., IRIONDO, JM. and TORRES, ME., 2003. Spatial analysis of genetic diversity as a tool for plant conservation. Biological Conservation, vol. 113, no. 3, p. 351-365.

FRACARO, F., ZACARIA, J. and ECHEVERRIGARAY, S., 2005. RAPD based genetic relationships between populations of three chemotypes of Cunila galioides Benth. Biochemical Systematics and Ecology, vol. 33, no. 4, p. 409-417.

GUPTA, SK., KHANUJA, SPS. and KUMAR, S., 2001. In vitro micropropagation of Lippia alba. Current Science, vol. 81, no. 2, p. 206-210.

HEYWOOD, VH. and IRIONDO, JM., 2003. Plant conservation: old problems, new perspectives. Biological Conservation, vol. 113, no. 3, p. 321-335.

KESKITALO, M., PEHU, E. and SIMON, JE., 2001. Variation in volatile compounds from tansy (Tanacetum vulgare L.) related to genetic and morphological differences of genotypes. Biochemical Systematics and Ecology, vol. 29, no. 3, p. 267-285.

LORENZO, D.,PAZ, D., DAVIES,P.,VILA, R.,CAÑIGUERAL, S. and DELLACASSA, E., 2001. Composition of a new essential oil type of Lippia alba (Mill.) Brown from Ururguay. Flavour and Fragrance Journal, vol. 16, no. 5, p. 356-359. N.E.

MARTINS, ER. and SANTOS, RHS., 1995. Plantas medicinais: uma alternativa terapêutica de baixo custo. Viçosa: Universidade Federal de Viçosa - UFV.

MATOS, FJA., 1998. Farmácias vivas. 3 ed. Fortaleza: Universidade Federal do Ceará - UFC.
MATTIONI, C., CASASOli, M., GONZALEZ, M. and IPINZA, R., 2002. Comparison of ISSR and RAPD markers to characterize three Chilean Nothofagus species. Theoretical and Applied Genetics, vol. 104, no. 6-7, p. 1064-1070.

NAN, P., PENG, S., SHI, S., REN, H., YANG, J. and ZHONG, Y., 2003. Interpopulation congruence in Chinese Primula ovalifolia revaled by chemical and molecular markers using essential oils and ISSRs. Zeitschrift für Naturforschung. Journal of biosciences, vol. 58, no. 1-2, p. 57-61.

PEAKALL, R. and SMOUSE, PE., 2001. GenALEx V5: genetic analysis in excel. Population genetic software for teaching and research. Canberra: Australian National University.

SANGWAN, RS., SANGWAN, NS., JAIN, DC., KUMAR, S. and RANADE, AS., 1999. RAPD profile based genetic characterization of chemotypic variants of Artemisia аппиа L. Biochemistry and Molecular Biology International, vol. 47, no. 6, p. 935-944.

SENATORE, F. and RIGANO, D., 2001. Essential oil of two Lippia spp. (Verbenaceae) growing wild in Guatemala. Flavour and Fragrance Journal, vol. 16, no. 3, p. 169-171.

SNEATH, PHA. and SOKAL, RR., 1973. Numerical taxonomy. San Francisco: Freeman.

STASHENKO, EE., JARAMILLO, BE. and MARTÍNEZ, JR., 2003. Comparación de la composición química y de la actividad antioxidante in vitro de los metabolitos secundarios volátiles de plantas de la familia Verbenaceae. Revista de la Academia. Colombiana de Ciencia, vol. 27, no. 105, p. 579-598.

TERBLANCHÉ, FC. and KORNELIUS, G., 1996. Essential oil constituents of the genus Lippia (Verbenaceae): a literature review. Journal of Essential Oil Research, vol. 8, no. 5, p. 471-485.

TORRES, E., IRIONDO, JM. and PÉREZ, C., 2003. Genetic structure of an endangered plant, Antirrhinum microphyllum (Scrophulariaceae): allozyme and RAPD analysis. American Journal of Botany, vol. 90, no. 1, p. 85-92.

VALE, TG., MATOS, FJA., LIMA, TCM. and VIANA, GSB., 1999. Behavioral effects of essential oils from Lippia alva (Mill.) N.E. Brown chemotypes. Journal of Ethnopharmacology, vol. 67, no. 2, p. 127-133.

VIANA, GSB., VALE, TG., RAO, VSN. and MATOS, FJA., 1998. Analgesic and antiinflamatory effects of two chemotypes of Lippia alba (Mill.) N.E. Brown: a comparative study. Pharmaceutical Biology, vol. 36, no. 5, p. 1-5.

VICCINI, LF., SOUZA Da COSTA, DC., MACHADO, MA. and CAMPOS, AL, 2004. Genetic diversity among nine species of Lippia (Verbenaceae) based on RAPD markers. Plant Systematics and Evolution, vol. 246, no. 1-2, p. 1-8.

WILLIAMS, JGK., KUBELIK, AR., LIVAK, KL., RAFALSKI, JA. and TINGEY, SV., 1990. DNA polymorphisms amplified by arbitrary primers are useful as genetic markers. Nucleic Acids Research, vol. 18, no. 22, p. 6531-6535.

ZIETKIEWICZ, E., RAFALSKI, A. and LABUDA, D., 1994. Genome fingerprinting by simple Sequence Repeat (SSR): anchored polymerase chain reaction amplification. Genomics, vol. 20, no. 2, p. 176-183.

ZOGHBI, MGB., ANDRADE, EHA., SANTOS, AS., SILVA, MHL. and MAIA, JGS., 1998. Essential oil of Lippia alba (Mill.) N.E. Br. Grown wild in Brazilian Amazon. Flavour and Fragrance Journal, vol. 13, no. 1, p. 47-48. 